\title{
Rein's trajectories for the restricted three-body problem. Application to the Earth-Moon system
}

\section{Mihai BARbosu and Tiberiu Oproiu}

\section{ABSTRACT.}

This paper presents trajectories of a spacecraft moving in the gravitational field given by Rein's model for the restricted three-body problem. For various initial conditions, closed orbits are determined using Maple's numerical capabilities for ODE.

Applications to the Earth-Moon system are considered, with trajectories computed around the stable $\bar{L}_{4}$ Lagrangian point.

\section{REFERENCES}

[1] Barbosu, M. and Oproiu, T., Equilibrium points in the Rein's Model for Semi-averaged Planar Elliptic Restricted Three-Body Problem, Ovidius Univ. Annals Series, 1 (2009), No. 11, 125-130

[2] Pál, Á., A Mathematical Model of the Elliptical Restricted Three-Body Problem, Babeş-Bolyai Univ., Fac. Math. Res. Sem., 4 (1982), No. 3, 114-123

[3] Pál, Á., Application of the Model of the Elliptical Restricted Three-Body Problem to the Study of the Binary Stars, Babeş-Bolyai Univ., Fac. Math. Res. Sem., 5 (1983), No. 4, 9

[4] Pál, Á. and Oproiu, T., On the Determination of the Collinear Double Points in the Averaged Plane Elliptic Restricted Three-Body Problem, Babeş-Bolyai Univ., Fac. Math. Phys. Res. Sem., 10 (1988), No. 10, 135-147

[5] Pál, Á. and Oproiu, T., Determination of the Slopes of "Zero Relative Velocity" Curves from the Elliptic Restricted Three-Body Problem with an Averaging Method, Romanian Astron. J., 1 (1991), 97-102

[6] Pál, Á., Oproiu, T. and Macaria, R., Soluţii de echilibru în problema restrânsă eliptică a celor trei corpuri, Communication held at the Scientific Session dedicated to the centenary of the birth of Professor Constantin Pârvulescu, Bucharest, 8-9 November 1990

[7] Rein, N. F., O kachestvennykh kharakteristikakh dvizheniya v uproschchennoj poluosrednennoj ellipticheskikh ogranichennoj probleme trekh tel, Trudy GAIS, 14 (1940), 127-152

[8] Szebehely, V., Theory of Orbits. The Restricted Problem of Three Bodies, Academic Press, New York, London, 1967

DEPARTMENT OF MATHEMATICS

STATE UNIVERSITY OF NEW YORK AT BROCKPORT

350 NEW CAMPUS DR. BROCKPORT, NY, 14420, USA

E-mail address: mbarbosu@brockport.edu

Astronomical ObSERVATORY

CIREŞILOR 19, 400487 ClUJ-NAPOCA, ROMANIA

E-mail address: toproiueyahoo.com 